\title{
Modulating Role of D-Ribose-L-Cysteine on Oxidative Stress in Streptozotocin Induced Diabetes on Plasma Lipoprotein, Oxidative Status, Spermato- genesis and Steroidogenesis in Male Wistar Rats
}

\author{
${ }^{2}$ Department of Anatomy, Kogi State University, Anyigba, Nigeria \\ ${ }^{3}$ Department of Anatomy, University of Abuja, FCT Abuja, Nigeria \\ ${ }^{4}$ Department of Anatomy, Ladoke Akintola University of Technology, Ogbomoso, Nigeria
}

Adelakun Sunday Aderemi,4*, Omotoso Olusegun Dare ${ }^{2}$ and Aniah Julius Akomaye ${ }^{3}$

${ }^{1}$ Department of Human Anatomy, School of Health and Health Technology, Federal University of Technology, Akure, Nigeria

Submission: November 02, 2018; Published: December 13, 2018

*Corresponding author: Adelakun Sunday Aderemi, Department of Human Anatomy, School of Health and Health Technology, Federal University of Technology, PMB 704, Akure, Nigeria

\begin{abstract}
Introduction: Impart of D-Ribose-L-cysteine on plasma lipoprotein, oxidative status, spermatogenesis and steroidogenesis in male diabetic rats was investigated.

Methods: Twenty-four adult male wistar rats divided into four groups of six ( $\mathrm{n}=6)$ rats each, A: Nondiabetic control received $2 \mathrm{ml} / \mathrm{kg}$ body weight (bwt) distilled water, B: Diabetic control given distilled water as placebo, C: $30 \mathrm{mg} / \mathrm{kg}$ bwt of D-ribose-L-cysteine treated rats, D: Diabetic rats treated with $30 \mathrm{mg} / \mathrm{kg}$ bwt of D-ribose-L-cysteine twice a day via gastric intubation lasted for 28 days. Parameters tested include: fasting blood and serum glucose, lipid peroxide, sperm parameters and reproductive hormones.
\end{abstract}

Results: D-Ribose-L-Cysteine significantly decreased blood and serum glucose, total cholesterol, low density lipoprotein (LDL), high density lipoprotein (HDL), triglyceride, malondialdehyde (MDA) levels and significantly $(\mathrm{p}<0.05)$ improved sperm quality and reproductive hormone in diabetics' rats in comparison with normal control rats.

Conclusion: Ribose-L-Cysteine treatment exerted a protective effect against reproductive dysfunction, hyperglycemia and hyperlipidemia in diabetic rats.

Keywords: D-Ribose; L-Cysteine; Wistar rats; Diabetic rat; Sperm; Hormone; Streptozotocin

Abbreviations: DM: Diabetes Mellitus; ROS: Reactive Oxygen Species; FSH: Follicle Stimulating Hormone; LH: Luteinizing Hormone; STZ: Streptozotocin; TT: Testosterone; NC: Normal Control; DC: Diabetic Control; DRC: D-Ribose-L-Cysteine Treated Rats; DRCD: D-Ribose-L-Cysteine Treated Diabetic Rats Miu: Milli International Unit; Ng: Nanograms

\section{Introduction}

Diabetes mellitus (DM) is associated with the production of reactive oxygen species (ROS) and consequently oxidative stress, which promotes not only an alteration in the cellular redox state in the presence of chronic hyperglycaemia, but also reduces the ability of tissues to utilize carbohydrates, leading to disturbances in the metabolism of fat and protein $[1,2]$. It has been reported that chronic high blood glucose levels contributed to the formation of ROS, through several mechanisms such as glucose autoxidation, the oxidation of protein $[3,4]$ and non-enzymatic glycation of protein, [5] thus exacerbating oxidative stress. Diabetes mellitus has been associated with an increased risk of mortality and prevalence of cardiovascular disease. Atherosclerotic cardiovascular disease is the main source of morbidity and mortality in patients with diabetes [6].

In addition, oxidative stress may occur as a consequence of abnormalities in glucose and lipid metabolism, which favour hyperglycemia and dyslipidaemia. These phenomena are associated with the development of atherosclerosis and cardiovascular complications in diabetic patients [6,7]. Changes in lipid concentration and consequent disorders of lipid metabolism have been observed in diabetes mellitus [8]. With Ketosis of diabetes mellitus, hyperlipidaemia and hypercholesterolaemia may lead to increased level of lipid peroxidation. This enhances the oxidation of lipids and lipoproteins exposing a diabetic to dangers of atherosclerosis [9]. 


\section{Current Research in Diabetes \& Obesity Journal}

Hence there may be an elevated lipid peroxidation in the plasma of diabetic patients. The World Health Organization (WHO) has predicted that the number of patients with diabetes worldwide will double by the year 2025 , from the current number of approximately 150 million to 300 million [2]. It is shown that DM has detrimental effects on sperm parameters in human and experimental animals.DM may affect male reproductive functions at multiple levels including its detrimental effects on endocrine control of spermatogenesis and/or by impairing erection and ejaculation [10]. Insulin-dependent diabetes is accompanied by reduced semen volume and decreased vitality and motility of the spermatozoa, but no change in seminal viscosity [11].

Infertility is one of the major health problems in life, and available evidence suggests that $50 \%$ of couples with infertility are male related [12]. Several conditions can interfere with spermatogenesis and reduce sperm quality and production. More factors such as drug treatment, chemotherapy, toxins, air pollutions and insufficient vitamins intake have harmful effects on spermatogenesis and sperm normal production [13]. Several studies have reported that antioxidants and vitamin in diet can protect sperm DNA from free radicals and increase blood-testes barrier stability [14].

Riboceine is one of the synthetic antioxidants that help cells produce glutathione on-demand. The active ingredient of riboceine is D-Ribose-L-Cysteine. Whole glutathione consumption cannot be effective because it would be destroyed in the digestion process before reaching the cell. The ribose component of the Riboceine solves these challenges by effectively protecting and delivering the fragile cysteine molecule, enabling the cells to produce glutathione when the cells need it most [15].

L-cysteine is called a semi-essential amino acid because humans can synthesize it from the amino acid methionine $[16,17]$ along with a host of proteins, L-cysteine is a precursor of glutathione, which is considered pivotal for the detoxification of cellular oxidative stress [16]. Elevated levels of oxidative stress can potentially impair cellular glucose metabolism via a variety of mechanisms, including redox imbalance and insulin resistance [18]. Ammon et al. [19] reported that addition of L-cysteine to the culture medium potentiates the glucose induced insulin release in pancreatic islets isolated from female Wistar rats. Dietary intake of when protein and alpha-lactoalbumin (cysteine rich proteins) lowers the oxidative stress and insulin resistance induced by sucrose in rats $[20,21]$. The present study focused the on ability of D-Ribose-L-Cysteine to promote spermatogenesis and modulate follicle stimulating hormone (FSH), luteinizing hormone (LH), testosterone concentration, lipid profile and oxidative stress.

\section{Materials and Methods}

\section{Chemical and riboceine preparation}

Streptozotocin (STZ) is purchased from Sigma Chemical Company St. Louis U.S.A. All assay kits were from Randox Laboratories Limited UK. All other chemicals (sodium citrate, chloroform) and reagents used were of analytical grade obtained from reputable manufacturers. Riboceine supplements were obtained from Max International, Salt Lake City, Utah, USA. They were dissolved in phosphate-buffered saline.

\section{Experimental animals}

Adult male wistar rats weighing between 150 - $200 \mathrm{~g}$ were obtained from the Animal House, Department of Anatomy, Ladoke Akintola University of Technology, Ogbomoso, Nigeria Animal Control Room in well ventilated plastic cages with 12:12 lightdark cycle at $27 \pm 1^{\circ} \mathrm{C}$. The animals were acclimatized in well ventilated cages under ambient environmental conditions for a period of two weeks before commencement of experiment. They were maintained on grower's mash (Farm support Feeds Plc, Ogbomoso, Oyo State) and provided with water ad libitum. All the experiments were conducted in accordance with international laboratory animal use and care guidelines [22]. Study protocols and ethical issues were approved by the Animal Research and Ethical Committee of the institution.

\section{Induction of diabetes}

Diabetes was induced in rats fasted overnight by a single intraperitoneal injection of freshly Prepared solution of streptozotocin (Sigma Chemicals Co., St Loius USA) at $65 \mathrm{mg} / \mathrm{kg}$ in $0.1 \mathrm{M}$ cold citrate buffer $\mathrm{pH} 4.5$. The animals were considered as diabetic if the blood glucose values of the overnight fasted rats, were $>250 \mathrm{mg} / \mathrm{dl}$ on the third day following streptozotocin injection [23].

\section{Experimental design}

Twenty-four ( $n=24)$ adult male wistar rats were used for this study randomly divided into four groups of six rats each. Group A: Control given only the citrate buffer (0.01M, pH 4.5), Group B: untreated diabetic (diabetic control), made with a single dose of streptozotocin $(65 \mathrm{mg} / \mathrm{kg}$ body weight) by intraperitoneal route. Group C: $30 \mathrm{mg} / \mathrm{kg}$ body weight of D-Ribose-L-cysteine treated rats Group D: Diabetic rats treated with $30 \mathrm{mg} / \mathrm{kg}$ body weight of D-Ribose-L-cysteine twice a day via gastric intubation. The diabetic rats were then kept for the next 24 hours on $5 \%$ glucose solution bottles in their cages to prevent hypoglycemia. Blood was collected on every 3 days through the rat's tail vein for glucose estimation using One Touch Glucometer; After 28 days of treatment the body weight and fasting blood glucose, serum glucose of the animals was again determined.

\section{Analytical procedure}

At the end of 28 days of treatment, twelve hours after the last treatment and after the last food given the animals were anaesthetized with chloroform and sacrificed. The blood of each animal was separately collected by cardiac puncture in non heparinised tubes and allowed to clot. Serum was harvested following centrifugation using Wisperfuge model 1384 centrifuge (Tamson, Holland) at $3000 \mathrm{rpm}$ for $15 \mathrm{~min}$ to facilitate separation. The serum thus obtained was used for malondialdehyde level MDA (product of lipid peroxidation), total cholesterol, LDLcholesterol, HDL-cholesterol and triglycerides estimations. Serum 


\section{Current Research in Diabetes \& Obesity Journal}

MDA was measured by a thiobarbituric acid assay procedure, [24] which was calibrated using 1,1,3,3, -tetraethoxypropane (Sigma Chemicals, St. Louis, MO, USA.) as a standard. All analysis was completed within 24 hours of sample collection. Results were expressed as nanomoles of MDA per millimeter of serum. Serum total cholesterol was estimated using method of Zak [25] plasma triglyceride estimated by method of Mendez et al. [26] HDL-C by Lopez- Vitrella et al. [27] LDL-C and VLDL triglyceride values were calculated by a modification of the friedewald formular [28].

\section{Semen analysis}

The cauda epididymis of the rats was incised and a drop of epididymal fluid delivered onto a glass slide, covered by a 22 . $22 \mathrm{~mm}$ cover slip and examined under the light microscope at a magnification of $\cdot 100$ while evaluating different fields [29]. For the purpose of this study, motility was classified as either motile or non-motile/dead [30] After assessing different microscopic fields, the relative percentage of motile sperm was estimated and reported to the nearest 5\% using the subjective determination of motility [31]. The sperm count was determined using the Neubauer improved haemocytometer. Epididymal fluid ratio of 1:20 was prepared by adding $0.1 \mathrm{ml}$ of fluid to $1.9 \mathrm{ml}$ of water.

Result

Table 1: Body weight, blood glucose and serum glucose in normal, diabetic and D-Ribose-L-Cysteine treated diabetic rats.

\begin{tabular}{|c|c|c|c|c|c|c|}
\hline Groups & \multicolumn{3}{|c|}{ Body Weight (g) } & \multicolumn{3}{c|}{ Fasting Blood Glucose (mg/dl) } \\
\hline & Initial & Final & Weight Gain & Initial & Final & $\begin{array}{c}\text { Serum Glucose } \\
\text { (mmol/L) }\end{array}$ \\
\hline Normal Control & $178.6 \pm 19.4$ & $202.4 \pm 13.5$ & $24 \pm 5.9$ & $79.2 \pm 8.2$ & $77.5 \pm 5.4$ & $5.3 \pm 1.3$ \\
\hline Diabetic control & $166.8 \pm 14.7$ & $141.7 \pm 7.9^{*}$ & $-25 \pm 7.0$ & $382.5 \pm 47.7$ & $327.3 \pm 31.8^{*}$ & $12.5 \pm 1.3^{* *}$ \\
\hline D-Ribose-L-Cysteine treated rats & $162.7 \pm 11.4$ & $199.9 \pm 14.4^{*}$ & $37.2 \pm 3.0^{* *}$ & $84.3 \pm 8.8$ & $78.4 \pm 3.8$ & $6.2 \pm 1.2$ \\
\hline $\begin{array}{c}\text { D-Ribose-L-Cysteine treated } \\
\text { diabetic rats }\end{array}$ & $159.8 \pm 9.9$ & $158.2 \pm 16.0^{* *}$ & $-1.6 \pm 6.1^{* *}$ & $425.2 \pm 38.2$ & $180.6 \pm 15.2^{* * \beta}$ & $8.7 \pm 1.2^{* *}$ \\
\hline
\end{tabular}

Values are expressed as Mean \pm SD, $n=6$ in each group, *Significantly different from normal control group $(p<0.05)$. ${ }^{*}$ Significantly different from normal and diabetic controls $(p<0.05)$. $\beta$ Significantly different from Initial Fasting Blood glucose $(p<0.05)$, One-Way ANOVA

Body weight, blood glucose and serum glucose in normal, diabetic, D-Ribose-L-Cysteine treated rats and D-Ribose-LCysteine treated diabetic rats. There was a significant increased $(\mathrm{p}<0.05)$ in fasting blood glucose and decreased $(\mathrm{p}<0.05)$ in body weight in streptozotocin induced diabetic rats in comparison with the normal control. The body weight slightly increased and the fasting blood glucose significantly decreased in diabetic rats when treated with D-Ribose-L-Cysteine. The serum glucose level in the diabetic control group $(12.5 \pm 1.3 \mathrm{mmo} / \mathrm{dl})$ was significantly $(\mathrm{P}<0.05)$ higher compared to normal control group $(5.3 \pm 1.3$ $\mathrm{mmol} / \mathrm{L}$ ), while treated diabetic rats showed a rather significant
The dilution was mixed thoroughly, and both sides of the counting chamber were scored, and the average taken. Spermatozoa within five of the red blood cell squares including those which lie across the outermost lines at the top and right sides were counted, while those at the bottom and left sides were left out. The number of spermatozoa counted was expressed in millions/ml [31].

\section{Hormone determination}

Hormonal profile of the following endocrine markers (Testosterone, Follicule stimulating hormone and Leutenizing hormone) was carried out using method of immunoassay (ELISA) method (Randox Laboratories Ltd, Admore Diamond Road, Crumlin, Co., Antrim, United Kingdom, Qt94QY). according to the manufactur-

\section{Data presentation and statistical analysis}

Data were expressed as Mean \pm SD. Statistical differences between the groups were evaluated by one-way ANOVA, followed by Dunnets comparison test to compare between treated and control groups. Differences yielding $\mathrm{p}<0.05$ were considered statistically significant. Statistical analyses of data were performed using GraphPad Prism 5 for Windows (GraphPad Software, San Diego, California, USA). er's instructions.

Table 2: Serum Lipid Peroxide, lipid profile in normal, diabetic, D-Ribose-L-Cysteine treated rats and D-Ribose-L-Cysteine treated diabetic rats.

\begin{tabular}{|c|c|c|c|c|c|}
\hline \multirow{2}{*}{ Groups } & \multicolumn{5}{|c|}{ Parameters } \\
\hline & $\begin{array}{c}\text { MDA (nmol/ } \\
\mathbf{m l})\end{array}$ & $\begin{array}{c}\text { Total Cholester- } \\
\text { ol (mg/d) }\end{array}$ & $\begin{array}{c}\text { HDL- Cholesterol } \\
\text { (mg/dl) }\end{array}$ & $\begin{array}{c}\text { LDL- Cholesterol } \\
\text { (mg/dl) }\end{array}$ & $\begin{array}{c}\text { Triglyceride } \\
\text { (mg/dl) }\end{array}$ \\
\hline Normal Control & $4.70 \pm 0.90$ & $107.50 \pm 7.80$ & $13.42 \pm 4.76$ & $44.88 \pm 14.19$ & $89.40 \pm 14.49$ \\
\hline Diabetic control & $6.77 \pm 0.78^{*}$ & $118.60 \pm 6.38^{*}$ & $62.10 \pm 13.43^{*}$ & $69.88 \pm 14.07^{*}$ & $110.60 \pm 14.97^{*}$ \\
\hline
\end{tabular}




\section{Current Research in Diabetes \& Obesity Journal}

\begin{tabular}{|c|c|c|c|c|c|}
\hline D-Ribose-L-Cysteine treated rats & $3.12 \pm 0.76^{* *}$ & $95.50 \pm 10.50^{* *}$ & $18.01 \pm 7.20^{* *}$ & $45.23 \pm 12.14$ & $85.49 \pm 13.80^{*}$ \\
\hline D-Ribose-L-Cysteine treated diabetic rats & $4.92 \pm 0.89^{* *}$ & $103.00 \pm 7.30^{*}$ & $42.00 \pm 9.41^{* *}$ & $32.51 \pm 12.81^{*}$ & $91.62 \pm 14.20^{*}$ \\
\hline
\end{tabular}

Values are expressed as Mean \pm SD, $n=6$ in each group, *Significantly different from normal control group $(p<0.05)$. ${ }^{* *}$ Significantly different from normal and diabetic controls $(p<0.05)$. $\beta$ Significantly different from Initial Fasting Blood glucose $(p<0.05)$, One-Way ANOVA

The mean values of Total cholesterol, HDL-cholesterol levels, parameters in normal, diabetic, D-Ribose-L-Cysteine treated rats LDL-cholesterol and triglycerides $(118.60 \pm 6.38,62.10 \pm 13.43$, $69.88 \pm 14.07$ and $110.60 \pm 14.97)$ were significantly higher $(\mathrm{p}<0.05)$ in diabetic control rats compared to the treated rats, treated diabetic rats, and normal control rats $(95.50 \pm 10.50$, 18.01 $\pm 7.20, \quad 45.23 \pm 12.14, \quad 85.49 \pm 13.80),(103.00 \pm 7.30$, $42.00 \pm 9.41, \quad 32.51 \pm 12.81,91.62 \pm 14.20)$ and (107.50 \pm 7.80 , $13.42 \pm 4.76,44.88 \pm 14.19,89.40 \pm 14.49$ ). LDL-cholesterol levels of rats treated with D-Ribose-L-Cysteine are not significantly different when compared with the normal control rats. Sperm

and D-Ribose-L-Cysteine treated diabetic rats.

\section{Sperm motility}

The mean sperm motility after 28days of treatment in the control group was $(85.7 \pm 9.1)$. The mean value sperm motility in diabetes group was significantly lower $(33.3 \pm 7.5, \mathrm{p}<0.05)$ when compared to the control group. The mean sperm motility in D-Ribose-L-Cysteine treated rats and D-Ribose-L-Cysteine treated diabetic rats was significantly high $(92.4 \pm 5.9$ and $67.6 \pm 9.6$, $\mathrm{p}<0.05$ ) when compared to the diabetic control group (Figure 1).

\section{Sperm morphology}

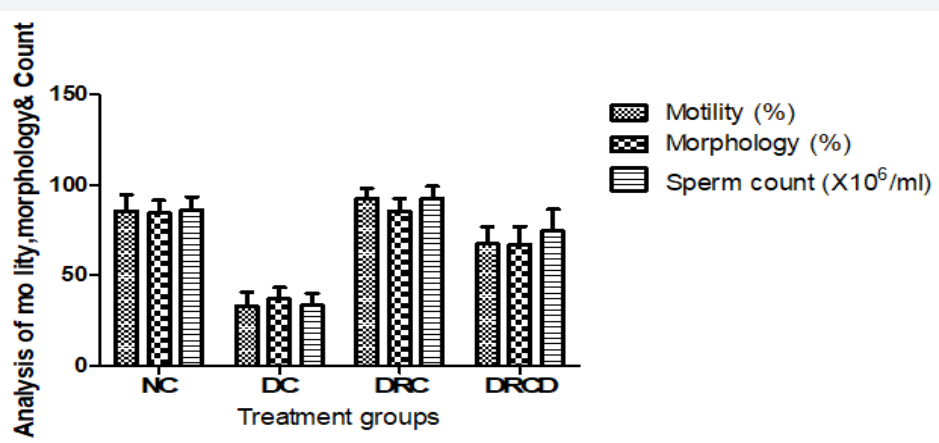

Figure 1: Sperm motility, morphology and count in normal, diabetic, D-Ribose-L-Cysteine treated rats and D-Ribose-L-Cysteine treated diabetic rats. Values are expressed as Mean $\pm S D, n=6$ in each group, *Significantly different from normal control group ( $p<0.05)$. ${ }^{* *}$ Significantly different from normal and diabetic controls $(p<0.05)$. One-Way ANOVA. NC: Normal Control; DC: Diabetic control; DRC: D-Ribose-L-Cysteine treated rats; DRCD: D-Ribose-L-Cysteine treated diabetic rats.

The mean sperm morphology after 28days of treatment in the control group was $(86.01 \pm 7.40$, $\mathrm{p}<0.05)$. The mean sperm morphology in diabetes control group was significantly lower $(37.00 \pm 6.30, \mathrm{p}<0.05)$ when compared to the control group. There was significant increased $(\mathrm{p}<0.05)$ in mean sperm morphology in D-Ribose-L-Cysteine treated rats and D-Ribose-L-Cysteine treated diabetic rats $(85.60 \pm 7.00$ and $66.90 \pm 10.1)$ in comparison with diabetic control group (Figure 1).

\section{Sperm count}

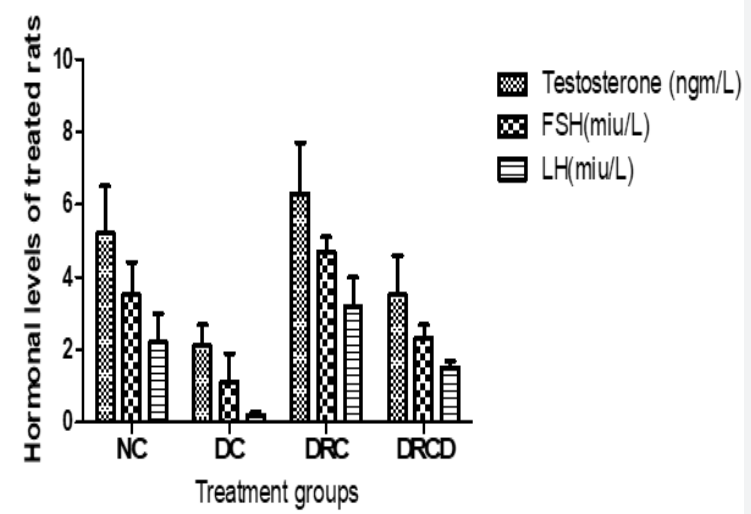

Figure 2: Serum Testosterone, Follicule stimulating hormone and Leutenizing hormone in normal, diabetic, D-Ribose-L-Cysteine treated rats and D-Ribose-L-Cysteine treated diabetic rats. Values are expressed as Mean $\pm S D, n=6$ in each group, *Significantly different from normal control group $(p<0.05)$. ${ }^{* *}$ Significantly different from normal and diabetic controls $(p<0.05)$. One-Way ANOVA, FSH: Follicle stimulating hormone; LH: Leutinizing hormone; Miu: Milli international unit; ng: Nanogramme; NC: Normal Control; DC: Diabetic control; DRC: D-Ribose-L-Cysteine treated rats; DRCD: D-Ribose-L-Cysteine treated diabetic rats. 


\section{Current Research in Diabetes \& Obesity Journal}

The mean sperm count value after 28days of treatment in the control group was $(86.01 \pm 7.40, \mathrm{p}<0.05)$. There was significant decreased in mean sperm count value in diabetic control group $(33.51 \pm 6.30, \mathrm{p}<0.05)$ when compared with normal control, D-Ribose-L-Cysteine treated rats and D-Ribose-L-Cysteine treated diabetic rats $(86.01 \pm 7.40,92.40 \pm 7.00$ and $74.71 \pm 11.80, \mathrm{p}<0.05)$ (Figure 1). Serum Testosterone, Follicule stimulating hormone and Leutenizing hormone in normal, diabetic, D-Ribose-LCysteine treated rats and D-Ribose-L-Cysteine treated diabetic rats. Compared with the control, animals in the diabetic control group had significantly reduced Serum Testosterone (TT), Follicule stimulating hormone (FSH) and Leutenizing hormone $(\mathrm{LH})(\mathrm{p}<0.05)$ levels however there was significant elevation ( $p$ $<0.05$ ) in mean value of TT, FSH and LH of D-Ribose-L-Cysteine treated rats and D-Ribose-L-Cysteine treated diabetic rats when compared with diabetic control rats (Figure 2).

\section{Discussion}

This study was conducted in order to investigate the antidiabetic and antifertility activity of D-Ribose-L-Cysteine in STZ induced diabetes in rats. Induction of diabetes increased the fasting blood sugar in the diabetic male rats. Streptozocininduced hyperglycaemia has been described as a useful experimental model to study the activity of antidiabetic agents [32]. Streptozocin selectively destroyed the pancreatic insulin secreting $\beta$ cells, leaving less active cell resulting in a diabetic state [33] which was the observation in diabetic control of this study. The present results indicate significant increase in blood and serum glucose levels in diabetic rats. The administration of D-Ribose-L-Cysteine actually reduces the blood and serum glucose levels in diabetic rats. This suggests that the supplement has hypoglycemic activities which led to a fall in blood sugar levels after 28days of administration in diabetic rats.

This study confirms the earlier findings that D-RiboseL-Cysteine has anti diabetic effect, L-Cysteine supplemented diabetic rats showed significantly lower $(p<0.05)$ glucose levels compared with diabetics control rats after 8 weeks of supplementation [34]. Our data shows that the rats' body weight decreased during the course of diabetes; these results were in accordance as reported by Ozdemir et al. [35], who attributed the reduction of body weight to the breakdown of tissue protein in the diabetic group. Diabetes causes a significant increment in skeletal muscle catabolism along with a decline in protein synthesis [36] Diabetes provoked a state of oxidative injury that was proved by an increase in levels of MDA. Mustafa et al. [37] reported a noticeable increase in lipid peroxidation product, MDA, levels in diabetic rats. In diabetes, the levels of serum lipids (cholesterol, free fatty acids and phospholipids) are usually elevated. The marked hyperlipaemia that characterizes the diabetic state is a consequence of the uninhibited actions of lipolytic hormones on the fat depots $[38,39]$.

Accelerated, $\beta$-oxidation stemming from increased fat mobilization (a consequence of insulin deprivation) generates a high concentration of acetyl CoA in the liver and is channeled to cholesterol and triacylglycerol synthesis given that fatty acid synthesis is impaired. These are usually exported to blood as VLDL where they also meet decreased utilization as a result of the inhibition of degradation-hormone sensitive lipoprotein lipase, by lack of insulin. These accumulate in blood to constitute hypercholesterolemia and triacylglycerolemia of diabetes as evident in this study. Induction of diabetes in this study caused significant increase serum triglycerides, total cholesterol, LDL cholesterol, HDL cholesterol and serum MDA in diabetic controls rats compared to normal control rats are in conformation with previous reports documenting elevated serum triglyceride and lipid peroxide levels in diabetic subjects [8].

In this study administration of D-Ribose-L-Cysteine significantly reduced triglyceride and suppressed free radical induced oxidative damage. This may be due to the anti-oxidative protective effects of D-ribose and L-cysteine. The presence of cysteine in the body's cells enables the production of glutathione, while ribose produces cellular energy. It is the interaction between D-ribose and L-cysteine that facilitates the production of glutathione. The glutathione within the cell protects against destruction from free-radical damage. Providing support to glutathione, improves ATP production by allowing mitochondria to manufacture ATP, controlling free radicals on an ongoing basis.

In current study results revealed that diabetes could be a predisposing factor to male infertility as recorded in the semen parameters (Figure 1). This is due to the fact that hyperglycaemia which is seen in diabetes was a consequence of failure of glucose to enter the cells of the testes grossly affected the Sertoli and Leydig cells which are to produce testosterone and sperm cells through spermatogenesis, this provoke possible development of low testosterone level/hypogonadism becomes very high, hypogonadism would result to reduction in the rate of spermatogenesis and finally the sperm count, motility and morphology. This was in consonance with previous report of researchers who established a bidirectional relationship between diabetes and hypogonadism, stating that diabetes could result to infertility in male rats $[40,41]$.

Hyperglycemia of diabetic's mellitus elevate the level of ROS that produces DNA destruction in testis and a major reduction in sperm parameters such as sperm motility, count, and viability [42]. However D-Ribose-L-Cysteine improves the sperm quality by scavenging the ROS and activate testicular enzymatic antioxidant status which support the report of Benedict et al. [15] that D-ribose and L-cysteine (Riboceine) was found to boost fertility in male Sprague-Dawley rats. D-ribose and L-cysteine at a dose of $30 \mathrm{mg} / \mathrm{kg}$ of body weight significantly boosted andrological parameters. Diabetic rats exhibit a marked decrease in sperm concentration, live sperm percentage, and an increased sperm abnormality which is in accordance as reported by Scarano et al. [43], that diabetic rats had pronounced reduction in sperm quantity and quality due to associated oxidative injuries. Also, diabetes-induced oxidative-stress has been reported to cause peroxidation of sperm membrane lipid which might interfere 


\section{Current Research in Diabetes \& Obesity Journal}

with membrane fluidity and transport processes [44]. In view of this, appearance of various abnormal sperm shapes could be due to abnormal membrane or cellular and nuclear changes induced by diabetes [45]. Treatment of the diabetics rats with D-RiboseL-Cysteine prevents the increase in the amount of testis lipid peroxidation oxidation (LPO) in diabetic rats. In both diabetic rats [46] and humans, [47]. LPO was the major cause of sperm damage.

In this study there was significant reductions in Serum Testosterone (TT), Follicule stimulating hormone (FSH) and Leutenizing hormone (LH) levels in diabetics rats however there was significant elevation in mean value of TT, FSH and LH of D-Ribose-L-Cysteine treated rats and D-Ribose-L-Cysteine treated diabetic rats when compared with diabetic control rats (Figure 2). since testosterone is crucial for spermatogenesis and high testosterone level is essential for the normal physiology of seminiferous tubules [48] we therefore deduced from our finds that Ribose-L-Cysteine have potency to improve deteriorated TT, FSH and LH level which is crucial for the normal physiology of seminiferous tubules in male diabetic's rats.

\section{Conclusion}

In conclusion because of beneficiary effects D-Ribose and L-Cysteine (Riboceine) on treated rats and diabetics male rats. D-Ribose-L-Cysteine therefore revealed in current study to attenuate the oxidative stress in streptozotocin induced diabetes on plasma lipoprotein, oxidative status, spermatogenesis and steroidogenesis. D-Ribose-L-Cysteine supplementation could be used as an adjuvant therapy for the reduction of infertility in diabetics subject because of its potent antioxidant property.

\section{Source Funding}

This research did not receive any specific grant from any funding agency in the public, commercial or not-for-profit sector.

\section{Acknowledgments}

The Author wishes to acknowledge the contribution of technical staff of Department of Anatomy, Ladoke Akintola University of Technology, Ogbomoso, Nigeria throughout the course of the study.

\section{References}

1. Je HD, Shin CY, Park HS, Huh IH, Sohn UD (2001) The comparison of vitamin $\mathrm{C}$ and vitamin $\mathrm{E}$ on the protein oxidation of diabetic rats. J Auton Pharm 21(5-6): 231-236.

2. Coskun O, Kanter M, Korkmaz A, Oter S (2005) Quercetin, a flavonoi antioxidant, prevents and protects streptozotocin-induced oxidative stress and $\beta$-cell damage in rat pancreas. Pharmacol Res 51(12): 117123.

3. Bonnefont-Rousselot D, Bastard JP, Jaudon MC, Delattre J (2000) Consequences of the diabetic status on the oxidant/antioxidant balance. Diabetes Metab 26(3): 162-176.

4. Maritim AC, Sanders RA, Watkins JB (2002) Diabetes, oxidative stress, and antioxidants: A Review. J Biochem Moll Toxicol 17(1): 24-38.

5. Szaleczky E, Prechi J, Ruzicska E, Fehér J, Braun L, et al. (1998) Reduction of glycated hemoglobin levels by long term, high dose ascorbic acid supplementation in healthy and diabetic patients. Med Sci Monit 4(2): 241-244.

6. Bray TM (2000) Dietary Antioxidants and Assessment of Oxidative Stress. Nutr 16(7-8): 578-580.

7. Chertow B, Edwards JC (2004) Advances in Diabetes for the Milennium: Vitamins and Oxidant Stress in Diabetes and Its Complications. Medscape General Med 6(3): 1-10.

8. Ononogbu IC (1988) The role of lipid in the study and diagnosis of diabetes mellitus. Proceedings of the $1^{\text {st }}$ African Conference on Biochemistry of lipids 1: 57-69.

9. Halliwell B (1990) How to characterize a biological antioxidant. Free Radical Res Commun 9(1): 1-32.

10. Petroianu A, Alberti LR, Antonio M, de Melo B, de Almeida LM (2009) Relation between diabetes mellites and male fertility. Einstein 7: 407410.

11. Ricci G, Catizone A, Esposito R, Pisanti FA, Vietri MT, et al. (2009) Diabetic rat testes: morphological and functional alterations. Andrologia 41(6): 361-368.

12. Akang EN, Oremosu AA, Osinubi AA, Dosumu 00. Kusemiju TO, et al. (2015) Histomorphometric studies of the effects of Telfairia occidentalis on alcohol-induced gonado-toxicity in male rats. Toxicology Reports 2 : 968-975.

13. Mosher WD, Pratt WF (1991) Fecundity and infertility in the United States: incidence and trends. J Fertil Steril 56(2): 192-193.

14. Khaki A, Fathiazad F, Nouri M, Khaki A, Maleki NA, et al. (2010) Beneficial effects of quercetin on sperm parameters in streptozotocininduced diabetic male rats. Phytother Res 24(9): 1285-1291.

15. Benedict F, Opeyemi A, Mulikat O, Abraham O, Adeoye 0 (2017) Effect of D-ribose-L-cysteine on aluminum induced testicular damage in male Sprague-Dawley rats. JBRA Assisted Reproduction 21(2): 94-100.

16. Dröge W (2005) Oxidative stress and ageing: is ageing a cysteine deficiency syndrome? Phil Trans Royal Society 360 (1464): 2355-2372.

17. Elshorbagy AK, Nurk E, Gjesdal CG, Tell GS, Ueland PM, et al. (2008) Homocysteine, cysteine, and body composition in the Hordaland Homocysteine Study: does cysteine link amino acid and lipid metabolism? Am J Clin Nutr 88(3): 738-746.

18. Evans JL, Maddux BA, Goldfine ID (2005) The molecular basis for oxidative stress-induced insulin resistance. Antioxidant Redox Signal 7(7-8): 1040-1052.

19. Ammon HPT, Hehl KH, Enz G, Setiadi-Ranti A, Verspohl EJ (1986) Cysteine analogues potentiate glucose-induced insulin release in vitro. Diabetes 35(12): 1390-1396.

20. Blouet C, Mariotti F, Mikogami T, Tome D, Huneau JF (2007) Meal cysteine improves postprandial glucose control in rats fed a highsucrose meal. J Nutr Biochem 18(8): 519-524.

21. Blouet C, Mariotti F, Azzout-Marniche D, Mathé V, Mikogami T, et al (2007) Dietary cysteine alleviates sucrose-induced oxidative stress and insulin resistance. Free Radical Biol Med 42(7): 1089-1097.

22. Garber JC, Barbee WR, Bielitzki JT, Clayton LA, Donovan JC, et al. (2010) Guide for the Care and Use of Laboratory Animals. New York: The National Academies Press. p. 213

23. Burcelin R, Eddouks M, Maury J, Kande J, Assan R, et al. (1995) Excessive glucose production, rather than insulin resistance, accounts for hyperglycaemia in recent-onset Streptozotocin diabetic rats. Diabetologia 38(3): 283-290.

24. Albro PW, Corbelt JT, Schroeder JL (1986) Application of the thiobarbiturate assay to the measurement of lipid products in microsomes. Chem Biol Interact 86(3): 185-194. 


\section{Current Research in Diabetes \& Obesity Journal}

25. Zak B (1959) Determination of total cholesterol using reaction with ferric chloride and sulphuric acid. Am J Clin Path 27: 583-590.

26. Mendez A, Franklein J, Slahegan BH (1975) Simple manual method for determination of serum triglycerides. Clin Chem 21(6): 760-770.

27. Lopez-Vitrella MF, Stone P, Ellis S, Coltwell JA (1977) Cholesterol determination in high density lipoprotein, separated by three different methods. Clin Chem 23(5): 882-884.

28. Sandkamp M, Funke H, Schulter M, Kahlar E, Assman G (1990) Lipoprotein(a) is an independent risk factor for myocardial infarction at a young age. Clin Chem 36(1): 20-23.

29.(1999) World Health Organization. Laboratory Manual for the Examination of Human Semen and Sperm Cervical Mucus Interaction. Cambridge: Cambridge University Press, UK

30. Osinubi AA, Daramola AO, Noronha CC, Okanlawon AO, Ashiru OA (2007) The effect of quinine and ascorbic acid on rat testes. West Afr Med 26(3): 217-221.

31. Keel BA, Webster BW (1990) Handbook of the Laboratory Diagnosis and Treatment of Infertility. Boca Raton: CRC Press Incorporation, $p$. 37.

32. Szkudelski T (2001) The mechanism of alloxan and streptozotocin action in B cells of the rat pancreas. Physiology Ressearch 50(6): 536546.

33. Moore MC, Coate KC, Winnick JJ, Zhibo AN, Cherrington AD (2012) Regulation of hepatic glucose uptake and storage In vivo. Adv Nutr 3(3): 286-294.

34. Sushil KJ, Thirunavukkarasu V, Jennifer LC, Justin LR, Rebeca B (2009) L-cysteine supplementation lowers blood glucose, glycated hemoglobin, CRP, MCP-1, oxidative stress and inhibits NFkB activation in the livers of Zucker diabetic rats. Free Radic Biol Med 46(12): 16331638.

35. Ozdemir 0, Akalin PP, Baspinar N, Hatipoglu F (2009) Pathological changes in the acute phase of streptozotocin-induced diabetic rats. Bull Vet Inst Pulawy 53: 783-790.

36. Nair KS, Ford GC, Ekberg K, Fernqvist-Forbes E, Wahren J (1995) Protein dynamics in whole body and in splanchnic and leg tissues in type I diabetic patients. J Clin Investig 95(6): 2926-2937.

37. Mustafa SA, Essam AA, Ali HE, Rasha MS, Doaa HA, et al. (2017) Thymoquinone Defeats Diabetes-Induced Testicular Damage in Rats
Targeting Antioxidant, Inflammatory and Aromatase Expression. Int J Mol Sci 18(5): 919.

38. Abubakar G, Danladi AA, Sunday EA, Sani I (2009) Antidiabetic effect of Nauclea latifolia leaf ethanolic extract in Streptozotocin induced diabetic rats. Pharmacognosy Research 1(6): 392-395.

39. Nelson DL, Cox MM (2012) Lehninger principles of biochemistry. ( $3^{\text {rd }}$ edt), New York, Worth Publisher, pp. 560

40. Dockery F, Bulpit CI, Agarwal S, Donaldson M, Rajkumar C (2003) Testosterone suppression in men with prostate cancer leads to an increase in arterial stiffness and hyperinsulinaemia. Clin Sci (Lond) 104(2): 195-201.

41. Nishiyama T, Ishizaki F, Anraku T, Shimura H, Takahashi K (2005) The influence of androgen deprivation therapy on metabolism in patients with prostate cancer. J Clin Endocrinol Metab 90(2): 657-660.

42. Amaral S, Oliveira PJ, Ramalho-Santos J (2008) Diabetes and the impairment of reproductive function: Possible role of mitochondria and reactive oxygen species. Curr Diabetes Rev 4(1): 46-54.

43. Scarano W, Messias A, Oliva S, Klinefelter G, Kempinas W (2006) Sexual behavior, sperm quantity and quality after short-term streptozotocininduced hyperglycaemia in rats. Int J Androl 29(4): 482-488.

44. Sanocka D, Kurpisz M (2004) Reactive oxygen species and sperm cells. Reprod Biol Endocrinol 2(1): 12.

45. Suresh S, Prithiviraj E, Venkata Lakshmi N, Karthik Ganesh M, Ganesh L, et al. (2013) Effect of Mucuna pruriens (Linn.) on mitochondrial dysfunction and DNA damage in epididymal sperm of streptozotocin induced diabetic rat. J Ethnopharmacol 145(1): 32-41.

46. Nelli GB, AS K, Kilari EK (2013) Antidiabetic effect of $\alpha$-mangostin and its protective role in sexual dysfunction of streptozotocin induced diabetic male rats. Syst Biol Reprod Med 59(6): 319-328.

47. Karimi J, Goodarzi MT, Tavilani H, Khodadadi I, Amiri I (2011) Relationship between advanced glycation end products and increased lipid peroxidation in semen of diabetic men. Diabetes Res Clin Pract 91(1): 61-66

48. Sharpe RM, Kerr JB, McKinnell C, Millar M (1994) Temporal relationship between androgen-dependent changes in the volume of seminiferous tubule fluid, lumen size and seminiferous tubule protein secretion in rats. J Reprod Fertil 101: 193-198.

Your next submission with Juniper Publishers
will reach you the below assets
- Quality Editorial service
- Swift Peer Review
- Reprints availability
- E-prints Service
- Manuscript Podcast for convenient understanding
- Global attainment for your research
- Manuscript accessibility in different formats
( Pdf, E-pub, Full Text, Audio)
- Unceasing customer service
Track the below URL for one-step submission
https://juniperpublishers.com/online-submission.php

